\title{
Study of prevalence of anemia among pregnant women attending antenatal checkup in a rural teaching hospital in Telangana, India
}

\author{
Shridevi* \\ Department of Obstetrics and Gynecology, Maheshwara Medical College and Hospital, Patancheru, Telangana, India \\ Received: 22 May 2018 \\ Accepted: 04 June 2018 \\ *Correspondence: \\ Dr. Shridevi, \\ E-mail: k.shriobgy@gmail.com \\ Copyright: (C) the author(s), publisher and licensee Medip Academy. This is an open-access article distributed under \\ the terms of the Creative Commons Attribution Non-Commercial License, which permits unrestricted non-commercial \\ use, distribution, and reproduction in any medium, provided the original work is properly cited.
}

\begin{abstract}
Background: Anemia during pregnancy is a major cause of morbidity and mortality in pregnant women in developing countries and has both maternal and fetal consequences. The objective of the present study was to evaluate the prevalence of anemia among pregnant women attending antenatal checkup in a rural teaching hospital in Telangana.

Methods: It is a hospital based cross-sectional observational study conducted in the department of Obstetrics and Gynecology at Maheshwara Medical College and Hospital, Telangana for duration of two years from March 2016 to April 2018. A total of 600 cases were studied and screened. Prevalence of anemia was calculated. Anemia was classified morphologically based on peripheral smear findings and classified as microcytic hypochromic, macrocytic, dimorphic anemia, normocytic normochromic anemia and normocytic hypochromic anemia. Based on hemoglobin values anemia was classified into mild, moderate, and severe anemia.

Results: Prevalence of anemia in pregnancy in rural Telangana was about 20\%. Age-wise, majority (58.3\%) of the patients were between 21 to 25 years. Gravida more than 2 were more $66.6 \%(400 / 600)$ when compared to lower parity. Among 600 cases, 140 pregnant women (23.3\%) suffered with mild anemia, 340 cases $(56.6 \%)$ with moderate anemia and $20 \%$ with severe anaemia. Morphologically, microcytic hypochromic type i.e., iron deficiency anaemia was the most common.

Conclusions: Anemia in pregnancy in rural Telangana is quite high and was found to be $20 \%$ in routine antenatal outpatient cases. Multiple pregnancies and low level of education indirectly contribute to anemia of pregnancy. Education and awareness about anemia in pregnancy can lead to better fetal and maternal outcomes.
\end{abstract}

Keywords: Anemia in pregnancy, Educational status in pregnant women, Hemoglobin estimation

\section{INTRODUCTION}

Anaemia has a significant public health burden in developing nations. ${ }^{1,2}$ Anaemia is never a diagnosis-it occurs secondary to an underlying disease process. Technically, anaemia defines a state in which an individual's haemoglobin concentration (red cell mass) falls two standard deviations below the reference intervals in a particular population (individuals of similar age, gender and geographical location)..$^{3,4}$
In other words, the cut-off for anaemia depends on variables such as biologic age, gender, race, altitude above sea level, pregnancy, smoking status and others. ${ }^{5}$

According to the World Health Organization (WHO) up to $41.8 \%$ of all women living in developing countries are anaemic. ${ }^{6}$ In India, National Family Health Survey - 2 in 1998 to 99 showed that $54 \%$ of women in rural and $46 \%$ women in urban areas are anaemic. ${ }^{7}$ The relative prevalence of mild, moderate, and severe anemia are $13 \%, 57 \%$ and $12 \%$ respectively in India (ICMR data). 
According to WHO, hemoglobin level below $11 \mathrm{gm} / \mathrm{dl}$ in pregnant women constitutes anemia and hemoglobin below $7 \mathrm{gm} / \mathrm{dl}$ is considered severe anemia. The Center for Disease Control and Prevention (1990) defines anemia as less than $11 \mathrm{gm} / \mathrm{dl}$ in the first and third trimester and less than $10.5 \mathrm{gm} / \mathrm{dl}$ in second trimester. ${ }^{8,9}$

Serum Ferritin of 15 microgm/L is associated with iron deficiency anemia. ${ }^{9,10}$

Anemia during pregnancy is a major cause of morbidity and mortality of pregnant women in developing countries and has both maternal and fetal consequences. ${ }^{11-15}$ It is estimated that anemia causes more than 115,000 maternal and 591,000 perinatal deaths globally per year. ${ }^{16}$

The objective of the present study was to evaluate the prevalence of anemia among pregnant women attending antenatal check-up in a rural teaching hospital in Telangana.

\section{METHODS}

It was a hospital based cross-sectional observational study conducted in the department of Obstetrics and Gynecology at Maheshwara Medical College and Hospital, Telangana for duration of two years from March 2016 to April 2018. A total of 600 cases were and screened and studied. Informed consent was taken from all the pregnant women who were included in the study. No ethical issues were involved in the study.

Thorough clinical history was taken from all the cases who attended the antenatal outpatient clinic including gravida, parity, number of abortions, number of live and still births, occupation, personal history, dietary history, socio-economic status and type of family whether joint or nuclear type.

General examination was done with special emphasis on signs of anaemia like pallor, icterus, koilonychia, lymphadenopathy and edema. The tests were done on first antenatal visit of the patient irrespective of the trimester.

Venous blood samples collected in EDTA of all 600 cases were sent to department of Pathology (central laboratory) for routine investigations that included Hemoglobin estimation, complete hemogram, peripheral smear examination, reticulocyte count.

Peripheral smears were taken from all the samples and stained by Leishman's stain. Morphology of RBC, WBC and platelets were studied. Automated Hematology analyzer (Horiba 3-part analyzer) was used.

PCV, MCV, MCH, MCHC and RDW were determined by the automated cell counter. Normal values were taken as follows: PCV 35-45\%, MCV 77-95fl, MCH 25-33pg, MCHC 31-37gm/dl and RDW 14.5-16.5.
Anemia was classified based on hemoglobin values into mild, moderate and severe anemia.

Anemia was classified morphologically based on peripheral smear findings and classified as Microcytic hypochromic type, macrocytic type, dimorphic anemia and normocytic normochromic anemia.

\section{Inclusion criteria}

- All pregnant women attending antenatal clinics

- Age group from 18 years to 35 years.

\section{Exclusion criteria}

- $\quad$ Age group more than 35 years

- Pregnant women with chronic medical diseases

- Known cases of haemolytic anemias

- Bleeding diathesis

- Ante partum bleeding.

\section{RESULTS}

Total number of pregnant women attending antenatal clinic for duration of 2 years were 3000 . Total number of pregnant women with anemia were 600 .

Hence, prevalence was calculated as

Total no. of pregnant women with anemia x100/Total no. of pregnant women.

$600 \times 100 / 3000=20 \%$

Hence, prevalence of anemia in pregnancy in a teaching hospital in rural Telangana is about $20 \%$.

Table 1: Age-wise distribution of cases.

\begin{tabular}{|lll|}
\hline Age in years & \multicolumn{1}{|c|}{ No. of cases } & Percent \\
\hline $18-19$ & 50 & 8.3 \\
\hline $20-25$ & 350 & 58.3 \\
\hline $26-30$ & 125 & 20.8 \\
\hline $31-35$ & 75 & 12.5 \\
\hline Total & 600 & 100 \\
\hline
\end{tabular}

Age of 600 pregnant women with anemia ranged from 18 years to 35 years. The majority of the patients were between ages 20 to 25 years i.e., $350 / 600$ (58.3\%). About $8.3 \%(50 / 600)$ of all the pregnancies occurred among teenagers of 18 to 19 years (Table 1 ).

Table 2: Parity-wise distribution.

\begin{tabular}{|lll|}
\hline Parity & No. of cases & Percent \\
\hline Primigravida & 75 & 12.5 \\
\hline Gravid 2 & 125 & 20.8 \\
\hline More than 2 & 400 & 66.6 \\
\hline Total & 600 & 100 \\
\hline
\end{tabular}


In the present study, multigravida was more (400 cases, $66.6 \%$ ) in number.

Table 3: Educational status-wise distribution of cases.

\begin{tabular}{|c|c|c|}
\hline Education & No. of cases & Percent \\
\hline Illiterate & 250 & 41.6 \\
\hline Primary school & 200 & 33.3 \\
\hline Secondary school & 100 & 16.6 \\
\hline Graduate and or above & 50 & 8.3 \\
\hline Total & 600 & 100 \\
\hline
\end{tabular}

Majority of pregnant women (250/600 cases, $41.6 \%)$ with anemia were illiterate in our study who were unaware of folic acid and iron supplementation and importance of proper diet during pregnancy (Table 3).

\section{Dietary habits wise distribution}

There were 200 cases $(33.3 \%)$ that were purely vegetarians and $400(66.6 \%)$ cases that had mixed dietary habits of vegetarian and non-vegetarian diet. In the present study majority $(66.6 \%)$ of the pregnant women with anaemia were involved in agricultural work. Only $8.3 \%$ were working in companies as staff (Table 4).

Among 600 cases 140 pregnant women (23.3\%) suffered with mild anemia, 340 cases $(56.6 \%)$ with moderate degree of anaemia. $58.3 \%$ of pregnant women were between 20-25 years of age group. Severe anaemia was seen in $120(20 \%)$ among all 600 cases (Table 5).
Table 4: Occupational status wise distribution of cases.

\begin{tabular}{|lll|}
\hline Occupation & No. of cases & Percent \\
\hline House wife & 150 & 25.0 \\
\hline Agricultural & 400 & 66.6 \\
\hline $\begin{array}{l}\text { Working women } \\
\text { (service employees) }\end{array}$ & 50 & 8.3 \\
\hline Total & 600 & 100 \\
\hline
\end{tabular}

Table 5: Distribution of anaemia.

\begin{tabular}{|lllll|}
\hline $\begin{array}{l}\text { Age in } \\
\text { years }\end{array}$ & $\begin{array}{l}\text { Mild } \\
\text { anemia }\end{array}$ & $\begin{array}{l}\text { Moderate } \\
\text { anemia }\end{array}$ & $\begin{array}{l}\text { Severe } \\
\text { anemia }\end{array}$ & $\begin{array}{l}\text { Total } \\
\text { no. of } \\
\text { cases }\end{array}$ \\
\hline $18-19$ & 10 & 30 & 10 & 50 \\
\hline $20-25$ & 85 & 200 & 65 & 350 \\
\hline $26-30$ & 30 & 70 & 25 & 125 \\
\hline $31-35$ & 15 & 40 & 20 & 75 \\
\hline Total & 140 & 340 & 120 & 600 \\
\hline
\end{tabular}

Microcytic hypochromic anemia, i.e., iron deficiency anemia was the most common type of anemia in pregnancy and was seen in $82.3 \%$ cases followed by dimorphic type/nutritional deficiency type of anemia seen in $13 \%$ cases (Table 6).

\section{Distribution of type of family}

Cases belonging to joint families were more (400, $66.6 \%)$ as compared to nuclear families $(200,33.3 \%)$.

Table 6: Morphological type of anaemia.

\begin{tabular}{|llllll|}
\hline Age in years & $\begin{array}{l}\text { Microcytic } \\
\text { hypochromic }\end{array}$ & Macrocytic & Dimorphic & $\begin{array}{l}\text { Normocytic } \\
\text { normochromic }\end{array}$ & Total cases \\
\hline $18-19$ & 36 & - & 14 & - & 50 \\
\hline $20-25$ & 295 & 5 & 43 & 7 & 350 \\
\hline $26-30$ & 103 & 4 & 11 & 2 & 125 \\
\hline $31-35$ & 60 & 3 & 10 & 16 & 75 \\
\hline Total & 494 & 12 & 78 & 600 \\
\hline
\end{tabular}

\section{DISCUSSION}

\section{Age distribution}

In the present study, the total number of participants were 600. The age distribution ranged from 18 years to 35 years. The majority of the patients ie, $58.3 \%$ were between ages 21 to 25 years.

Next common age group was between ages 26 to 30 years with $20.8 \%$ patients. $12.5 \%$ (75/600) were among women aged 31 to 35 years. In a study by Bereka et al the range of the respondents' age was 15 to 39 years, with a mean of 22.9 years and a standard deviation of 3.9 years. ${ }^{17}$ Mangla et al in a similar study observed a total of 850 participants and reported a mean age of participants as 26.17 years. $^{18}$

Rajamouli et al studied 269 pregnant women. ${ }^{19}$ In their study, $77.3 \%$ of pregnant women were between 20-29 years. Lokare et al also reported majority of their subjects between ages 20 to 29 years with an average age of 22.7 years. ${ }^{20}$ About $2 \%$ of all the pregnancies occurred among teenagers and 5\% were among women aged 30 years and above in their study. Present study findings compare well with the above authors. 


\section{Distribution of anemia}

In the present study, among 600 cases, 140 pregnant women $(23.3 \%)$ suffered with mild anemia, 340 cases $(56.6 \%)$ with moderate anemia and $20 \%$ of pregnant women had severe anemia. Rajamouli et al reported mild anemia in $28.0 \%$, moderate anemia in $36.8 \%$ and severe degree of anaemia in $6.9 \%$ of their cases. ${ }^{19}$

Taner et al observed that out of total 1221 women had come for delivery during the study period, 508 had a hemoglobin level $<11 \mathrm{~g} / \mathrm{dL}$ and 713 had a level of $\geq 11$ $\mathrm{g} / \mathrm{dL} .^{21}$ Mangla et al in a similar study reported mild, moderate, severe and very severe anaemia in $41.76 \%$, $37.05 \%, 15.88 \%$ and $3.29 \%$ of their cases respectively. ${ }^{18}$

\section{Prevalence of anaemia}

In the present study, prevalence of anemia in pregnancy in a rural teaching hospital in Telangana was about $20 \%$. Rajamouli and coworkers reported higher prevalence of anaemia $(43.9 \%)$ in second gravida and $25.7 \%$ in 2 nd trimester pregnant women. ${ }^{19}$ Mangla et al observed prevalence of anemia as $98 \%$ among the pregnant females in rural India in their study. ${ }^{18}$ Lokare et al observed the overall prevalence of anemia among pregnant women to be $87.2 \% .^{20}$ The prevalence of mild, moderate and severe anemia were observed as $24.7 \%$, $54.5 \%$, and $7.9 \%$, respectively.

\section{Educational status}

In the present study majority of pregnant women with anemia were illiterate who were unaware of folic acid, iron supplementation and importance of nutritious diet during pregnancy. Rate of illiteracy was $41.6 \%$ in our study. Bereka et al observed in their study that 301 $(72.2 \%)$ had no formal education while the remaining $27.8 \%$ were educated till primary level and above. ${ }^{17}$ Rajamouli et al also observed that in the education category, majority of the patients suffering with anaemia were illiterates $(46.4 \%)$ as compared with other education levels. ${ }^{19}$ Anaemia was less $(23.6 \%)$ in primary school educated population. Its prevalence was still low in secondary school (19.2\%) and graduates/postgraduate population (10.8\%). Mangla et al observed that $21.5 \%$ of their females were illiterate, while $19.76 \%$ and $16.7 \%$ had studied up to primary and secondary levels respectively. ${ }^{18}$ Remaining $42.47 \%$ were graduates or post graduates. Present study findings compare well with the above authors.

\section{Parity status}

In the present study, parity-wise, gravida more than 2 were more i.e., $66.6 \%$ when compared to Gravida 2 that were $20.8 \%$. Primigravida were $12.5 \%$ only. Mangla et al in their study observed that $25.52 \%$ were primigravida, $36.7 \%$ were para one and $16.0 \%$ were multipara. ${ }^{18}$

\section{Occupation status}

In the present study, majority of the pregnant women $(66.6 \%)$ with anemia were agricultural workers and only $8.3 \%$ were working in companies as staff. Housewives accounted for $25 \%$. Bereka et al observed $36.5 \%$ of their responding women were house-wives and $32.2 \%$ of them were milk and fuel wood sellers. ${ }^{17}$ In the study by Rajamouli et al high prevalence $(96.8 \%)$ of anemia was seen among housewives and agricultural labours, whereas, only $3.2 \%$ employees had anemia. ${ }^{19}$

\section{Type of family}

In the present study, 66.6\% (400/600) were living in joint family and $33.3 \%(200 / 600)$ were living as nuclear family. Lokare et al also observed similar findings of $45.4 \%$ belonging to joint family and $37.7 \%$ belonging to nuclear family. ${ }^{20}$

\section{Morphological type of anemia}

In the present study, most common type of anemia was reported as microcytic hypochromic type i.e., iron deficiency anaemia followed by folate deficiency anaemia. Almost $75 \%$ anaemias in pregnant women are iron deficiency type followed by folate and dimorphic anaemias as reported by other authors. ${ }^{22}$

\section{CONCLUSION}

Anemia in pregnancy in rural Telangana is quite high and was found to be $20 \%$ in routine antenatal outpatient cases. Multiple pregnancies and low level of education indirectly contribute to anemia of pregnancy. Education and awareness about anemia in pregnancy can lead to better fetal and maternal outcomes.

Funding: No funding sources Conflict of interest: None declared Ethical approval: Not required

\section{REFERENCES}

1. World Health Organization (2008) World-wide prevalence of anaemia 1993-2005. WHO, Geneva.

2. World Health Organization (1992). THe prevalence of anaemia in women: a tabulation of available information, Geneva.

3. Wiwanitkit V. Introduction to tropical anemia. Tropical Anaemia. Nova Science Publishers. New York. 2007;1:1-7.

4. Adewoyin AS. Approach to anaemia, diagnosis in developing countries: focus on aetiology and laboratory work-up. Int Blood Res Review. 2015;4(1):1-13.

5. Sullivan KM, Mei Z, Grummer-Strawn L, Parvanta I. Haemoglobin adjustments to define anaemia. Trop Med Int Health. 2008;13(10):1267-71. 
6. De Benoist B. eds. World-wide prevalence of anaemia 1993-2005. WHO Global database on anaemia. Geneva, World health organization, 2008.

7. Kennedy E, Meyers L. Dietary Reference Intakes: development and uses for assessment of micronutrient status of women-a global perspective. Am J Clin Nutr. 2005;81(5):1194S-7S.

8. World Health Organization. The prevalence of anemia in pregnancy, WHO Technical reports, 19921993.

9. Centers for Disease Control (CDC. CDC criteria for anemia in children and childbearing-aged women. MMWR. Morbidity and mortality weekly report. 1989;38(22):400.

10. Sharma JB. Nutritional anaemia during pregnancy in third world countries. Prog Obstet Gynaecol. 2003;15:103-22.

11. Akhtar M, Hassan I. Severe anaemia during late pregnancy. Case Reports Obstet Gynecol. 2012;2012.

12. Vivek RG, Halappanavar AB, Vivek PR, Halki SB, Maled VS, Deshpande PS. Prevalence of Anemia and its epidemiological. Determinants in Pregn Women. 2012;5(3):216-23.

13. Elzahrani SS. Prevalence of iron deficiency anemia among pregnant women attending antenatal clinics at Al-Hada Hospital. Canad J Med. 2012;3(1):10-4.

14. Raza N, Sarwar I, Munazza B, Ayub M, Suleman M. Assessment of iron deficiency in pregnant women by determining iron status. J Ayub Med Coll Abbottabad. 2011;23(2):36-40.

15. Brooker S, Hotez PJ, Bundy DA. Hookworm-related anaemia among pregnant women: a systematic review. PLOS Neglect Trop Dis. 2008:2(9):e291.

16. Salhan S, Tripathi V, Singh R, Gaikwad HS. Evaluation of hematological parameters in partial exchange and packed cell transfusion in treatment of severe anemia in pregnancy. Anemia. 2012;2012.

17. Bereka SG, Gudeta AN, Reta MA, Ayana LA. Prevalence and associated risk factors of anemia among pregnant women in rural part of JigJiga City, Eastern Ethiopia: a cross sectional study. J Preg Child Health. 2017;4(337):2.

18. Mangla M, Singla D. Prevalence of anaemia among pregnant women in rural India: a longitudinal observational study. In J Reprod Contracept Obstet Gynecol. 2016;5(10):3500-5.

19. Rajamouli J, Ravinder A, Reddy SCK, Pambi S. Study on Prevalence of Anemia among Pregnant Women attending Antenatal Clinic at Rural Health Training Centre (RHTC) and Chalmeda Anand Rao Institute of Medical Sciences Teaching Hospital, Karimnagar, Telangana. Int J Contemp Med Res. 2016;3(8):2388-91.

20. Lokare PO, Karanjekar VD, Gattani PL, Kulkarni AP. A study of prevalence of anemia and sociodemographic factors associated with anemia among pregnant women in Aurangabad city, India. Ann Nigerian Med. 2012;6(1):30-4.

21. Taner CE, Ekin A, Solmaz U, Gezer C, Çetin B, Keleşoğlu M, et al. Prevalence and risk factors of anemia among pregnant women attending a highvolume tertiary care center for delivery. J Turk German Gynecol Assoc. 2015;16(4):231.

22. Sifakis S, Phamakides G. Anemia in pregnancy. Ann New York Academy Sci. 2000;900(1):125-36.

Cite this article as: Shridevi. Study of prevalence of anemia among pregnant women attending antenatal checkup in a rural teaching hospital in Telangana, India. Int J Reprod Contracept Obstet Gynecol 2018;7:2612-6. 